\title{
KEPEKAAN KOMUNITAS : SEBUAH STUDI PENJAJAKAN TERHADAP KONSUMEN JASA KEUANGAN DI AMERIKA
}

\author{
Suharyono ${ }^{1}$ \\ ${ }^{1}$ Program Studi Manajemen Pascasarjana, Universitas Nasional \\ email : suharyono_unas@yahoo.co.id
}

Korespondensi : suharyono_unas@yahoo.co.id

\begin{abstract}
The purpose of this study is to develop and test the sensitivity of the measurement scale of the consumption community. The concept is tested in exploratory studies in the context of customer perception (custemer) of fiancial service companies. The design / method / research approach explains the marketing, banking, psychology and public policy literature. The scale of the consumption community scale is tested to determine exploratory validity and confirmatory factor analysis. Scale reliability analysis was also carried out. The findings, the result is the second-order construction of first-order construction, camaraderie, and cumulality, as well as social capital. This construction becomes a measure of the strong perception of consumers of the consumption community. Other evidence of its practical value is shown in 4 (four) findings. First, partial support was found that men would feel a greater sensitivity to the community than women. Second, there is a positive relationship between age and the perceived sensitivity of a community. Third, no real connection was found between various forms of financial institutions and customer sensitivity to the consumer community. Fourth, the same findings were obtained from the relationship between sensitivity and the longevity variable, and the Fifth, this research also documented limitations to the sensitivity of the consumption community construction due to exploratory naturality of the research effort. Originality/value-the scale formulated in this research is the first to measure the sensitivity of the community among customers of financial institutions.
\end{abstract}

Keywords: consumption, consumer behavior, financial institutions, form of research writings, service consumer

\begin{abstract}
Abstrak
Tujuan penelitian ini adalah untuk mengembangkan dan menguji kepekaan skala pengukuran komunitas konsumsi. Konsep yang diuji dalam studi eksploratory dalam konteks persepsi pelanggan (custemer) perusahaan jasa fiancial. Desain, metode, pendekatan riset ini menjelaskan mengenai pemasaran, perbankan, psikologi dan literatur kebijakan publik. Kepekaan skala komunitas konsumsi diuji untuk menentukan validitas exploratory dan analisis faktor konfirmatory. Analisis reliabilitas skala juga dilakukan. Temuan, hasilnya merupakan konstruksi second-order dari konstruksi first-order, persahabatan (camaraderie), dan kumunalitas, serta modal sosial. Konstruksi ini menjadi alat ukur dari kuatnya persepsi konsumen terhadap komunitas konsumsi. Bukti lain dari nilai praktisnya ditunjukkan dalam 4 (empat) temuan. Pertama, dukungan parsial ditemukan bahwa laki-laki akan merasa
\end{abstract}


kepekaan yang lebih besar terhadap komunitas ketimbang wanita. Kedua, terdapat hubungan positif antara usia dengan kepekaan yang dirasakan dari suatu komunitas. Ketiga, tidak ada hubungan nyata yang ditemukan antara berbagai bentuk lembaga-lembaga keuangan dan kepekaan pelanggan terhadap komunitas komsumsi. Keempat, temuan yang sama diperoleh dari hubungan antara kepekaan dengan komunitas debgan variabel usia lanjut (longevity), dan Kelima, riset ini juga mendokumentasikam keterbatasan terhadap kepekaan konstruksi komunitas konsumsi karena naturalitas exploratory dari upaya riset ini. Orisinalitas skala yang diformulasikan dalam riset ini adalah yang pertama untuk mengukur kepekaan komunitas antar pelanggan (customer) lembaga-lembaga keuangan.

Kata kunci: konsumsi, tingkah laku konsumen, lembaga-lembaga keuangan, bentuk tulisan-tulisan penelitian, konsumen jasa

\section{PENDAHULUAN}

Identifikasi subkultur konsumsi seperti bikers-pengendara sepeda (Schouten \& McAlexander, 1995) menyebabkan perubahan besar dalam studi terhadap tingkah laku konsumen, pemahaman bahwa sepeda motor bisa menjadi lebih dari sekedar moda transportasi alaternatif tidak sepenuhnya diapresiasikan, tetapi hingga komunitas pengendara Harley Davidson dianggap sebagai sumber loyalitas merek yang tidak diragukan (Oliver, 1999).

Implikasi terhadap marketer secara virtual bagi semua barang dan jasa komersial menjadi jelas, dalam hal ini loyalitas merek yang tegas akan menghasilkan ingatan pelanggan. Informasi yang terdapat di antara anggota komunitas konsumen, mengharuskan perusahaan memberikan konstribusi terhadap pertumbuhan pangsa pasar (market share) serta potensial terhadap dominasi pasar.

Dengan demikian, entusiasme bagi komunitas konsumsi sebagai topik riset telah tumbuh dengan cepat, dan konstribusi catatan oleh Kozinets (2001), dan Muniz \& O'Guinn (2001). Studi tingkah laku konsumsi pelanggan dan komunitas fokus pada produk-produk seperti judi kasino (Fossey et al, 2002), Harley Davidson dan Jeep Brandfests (Ambert, 1995), dan internet newsgroup (Fischer dan Bristor, 1996). Antusiasme terhadap komunitas merek juga diperluas pada internet (Kozinets 2002; Williams \& Cothrel, 2000).

Banyak perusahaan yang mempromosikan kepekaan komunitas antar pelanggan-pelanggannya. Bukan hanya Harley Davidson, tetapi juga DaimlerChrysler's, Jeep Cherokee, Toyota, Starbucks, Mattlel's Barbie, L'oreal, Kemper Funds, Sony Music, Lipton, Casteo, dan Adobe. Perusahaan konsultan yang membantu, membangun dan mendorong komunitas merek seperti Upshaw Consulting, Interband, Brand Strategy, Inc dan Telk City. Incorporated, Web site BBC, MSNBC, dan Fox News yang menyediakan blok-blok yang diafiliasikan dengan beberapa program populer perusahaan-perusahaan tersebut. Fans Saab dan Ford Bronco Automobiles, dan Machintosh Komputer (Muniz \& O'Guina, 2001), juga membentuk komunitas independent produsen dan retailer produk favoritnya. Komunitas konsumen ini bersifat indikatif, dan komitmen jangka panjang terhadap merek yang mana ownernya menganggapnya eksepsional. 
Perusahaan-perusahaan yang mensponsori dan mempromosikan komunitas merek untuk lebih mempelajari pelanggan-pelanggan perusahaan, serta bagaimana perusahaan berinteraksi dengan produk-produk perusahaan itu. Perusahaan juga melakukan hal tersebut untuk berterima kasih kepada pelanggannya. Dalam hal ini perusahaan mempromosikan ucapan-ucapan ini dilakukan oleh banyak produsen antara lain: Harley Davidson, dan individual dealer.

Banyak event-event yang awalnya dilaksanakan secara independen oleh pelanggan yang saat in didukung untuk mendapatkan tingkat kontrol terhadap perusahaan, dan untuk melindungi emage merek. Upaya yang sama juga dilakukan oleh sponsor pembuat film pada event-event dimana fan-made manga (1) terjual (Jenkins, 2004). Pada akhirnya perusahaan-perusahaan ini ingin menciptakan dalam pikiran pelanggannya suatu pertimbangan yang hanya terdiri dari satu produk (milik perusahaan) untuk menfasilitasi pertumbuhan dalam maket share, share-ofcustomer, dan profitabilitas.

Dalam hal ini, yang penting untuk formasi dan promosi komunitas merek adalah pemahaman karakteristik komunitas konsumsi. Iklan umum yang dishare ini penting untuk memperkuat loyalitas customer. Intrumen pengukuran yang penting untuk menentukan apakah para peserta dalam aktifitas komunitas konsumsi merasa dirinya sebagai member suatu kelompok yang jauh dari user merek lain dari barang atau jasa yang sama. Maka instrument survei akan memungkinkan perusahaan mengevaluasi dan meningkatkan upaya-upanya untuk mempromosikan kepekaan komunitas antar pelanggan.

Tujuan dari tulisan ini adalah untuk mengembangkan dan menguji kepekaan terhadap skala pengukuran komunitas konsumsi dari literatur marketing, psikologi, dan kebijakan publik. Ketika riset sebelumnya menggunakan metodologi etnografi (McAlexander et.al 2001; McAlexander et.al, 2003, Schouter \& McAlexander 1995), upaya ini adalah yang pertama ; menggunakan analisis kuantitatif. Hal penting yang bersifat sekunder dari riset ini adalah tingkah laku pelanggan dari lembaga-lembaga keuangan terhadap penyedia jasa keuangan perusahaan yang juga dibahas dalam artikel ini.

Perlu diketahui bahwa belum ada studi yang membahas kepekaan komunitas dalam industri jasa keuangan di Amerika. Sektor ekonomi ini dipilih atas beberapa alasan. Pertama, sektor ini sangat besar, dengan jumlah lembaga-lembaga kecil yang cukup banyak; ada lebih dari 8000 bank yang diklarifikasikan sebagai lembagalembaga komunitas oleh perusahaan Asuransi Deposit Federal. Kedua, hampir 9000 lembaga yang memiliki member diatur oleh adminisitrasi Unit Kredit Nasional. Ketiga, melayani lebih dari 80 juta konsumen, secara komparatif bank-bank Amerika \& Unit Kreditnya cukup besar.

Sebaliknya dengan industri jasa financial di Eropa yang lebih terkonsentrasi pada lembaga-lembaga yang lebih kecil. Di Inggris 2018 bank-bank dari anggota Asosiasi Banker Inggris terdiri atas 90\% bank-bank dengan aset negara (lebih dari 63 membantu society). Francis memiliki 334 bank komersial, 97 bank kooperatif, 31 bank tabungan, dan 21 bank kerjasama. Industri perbankan, sedikit berkonsentrasi di Jerman, dimana terdapat 2400 lembaga, dan dari 4500 bank di 27 negara merupakan anggota Federasi Banking Eropa melalui asosiasi bangking nasional. 
Tingkat konsentrasi industri banking Eropa juga diharapkan dapat tumbuh (Nellis et.al, 2000). Bagimanapun, terdapat sedikit konsentrasi institusi keuangan di Amerika dari pada di Eropa, yang mempumyai kompetisi kuat, dan dengan demikian terdapat kemiripan yang besar yang dapat dirasakan oleh pelanggan untuk memjadi member komunitas lembaga bagi pelanggan.

Kedua, lembaga-lembaga keuangan Amerika juga berbeda dengan yang ada di negara lain. Karena persyaratan regulatory yang ditetapkan oleh Community Reinvestment Act, yang mempersyaratkan bank-bank tersebut dan menghemat dokumen upaya-upaya perusahaan untuk memenuhi kebutuhan kredit area jasa perusahaan. Upaya-upaya ini membutuhkan periodik oleh otoritas regulatory, dan dengan demikian terdapat ekspektasi mendasar, dimana lembaga keuangan mempunyai kewajiban untuk mempromosikan kepekaan komunitas antar pelanggan perusahaan.

Ketiga, pelanggan bank-bank Amerika yang hanya puas menukar atau mengganti merek (Jones dan Sasser, 1995; Oliver 1999). Secara spesifik, telah diuji bahwa satu dari lima customer bank Amerika, mengganti bank setelah merger. Keempat, biaya memperoleh customer-customer baru antara lima hingga sepuluh kali yang dipersyaratkan untuk mempertahankan pelanggan (Rosenbarg, 1984; Vandermerwe, 1996).

Bahwa paling tidak, satu studi menemukan bahwa para customer akan mengevaluasi bank-bank kecil di Amerika, lebih disukai daripada bank-bank besar dengan network cabang nasional (Kaynak \& Harcur 2005). Tetapi ini tidak berarti bahwa kepekaan rasa keanggotaan dalam komunitas jasa financial tidak diharapkan ditemukan di antara customer bank dengan cakupan nasional.

\section{KAJIAN TEORETIS \\ Kepuasan dan Loyalitas}

Hubungan antara konsumen dengan lembaga keuangannya telah dipelajari dalam hal sikap pelanggan, persepsi kualitas jasa, kepuasan dan loyalitas. Batang tubuh dari riset ini menjelaskan bahwa terdapat hubungan antara periset yang membentuk fondasi teoretis untuk studi kepekaan komunitas antara konsumen dan penyedia jasa keuangannya. Misalkan, sikap customer bank di Inggris yang menghubungkan modus penghantaran jasa alternatif menemukan bahwa mayoritas $(58,8 \%)$ lebih suka menjalankan bisnis pada perorangan (Howcroft et.al, 2002).

Sikap pelanggan lembaga komunitas di Inggris lebih beragam daripada institusi nasional dalam hubungannya dengan image dan kenyamanan (Kynak dan Hancar,2005). Dimensi lain dari hubungan antara pelanggan dan bank-nya adalah kualitas jasa. Paling tidak, satu studi menemukan bahwa di Amerika, Rating kualitas customer unit kredit lebih tinggi daripada customer bank (Alfred \& Addams,2000). Tetapi, temuan berulang diperoleh ketika unit kredit dan pegawai bank di survei tentang hal yang berhubungan dengan kualitas jasa yang dirasakan oleh pegawai bank dari manajer bank tersebut; pegawai bank memberikan rating yang lebih tinggi kepada manajemen bank daripada kolega unit kreditnya (Allred, 2001).

Paling tidak, satu studi longitudinal yang melaksanakan instrument survet SERVQUAL menunjukkan bahwa sebuah bank di Inggris yang besar dapat 
meningkatkan persepsi customer terhadap kualitas jasa, meskipun memiliki masalah-masalah besar (Newman,2001). Studi lain (Oppewal \& Uriens, 2000) memformulasikan makna alternatif dari pengukuran kualitas jasa terhadap instrument SERVQUAL. Para peneliti ini, mengidentifikasi atribut terpenting (staff demeanor, resolusi komplain dan ketersediaan teller), juga meningkatkan service, nampaknya akan menaikkan market share (resolusi komplain). Implikasi terpenting dari peningkatan kualitas jasa adalah bahwa mereka memfasilitasi kepuasan pelanggan yang lebih tinggi (Oliver, 1993; Spreng \& Mackoy, 1996).

Kepuasan pelanggan merupakan salah satu topik yang paling di-riset dalam marketing konsumen. Lasser et.al (2000) mengindentifikasi pengukuran teknis/fungsional kualitas jasa sebagai yang paling reliable dalam memprediksi kepuasan pelanggan dalam survey-survey yang dilaksanakan di Amerika dan Amerika Selatan. Penanganan yang cepat terhadap permintaan pelanggan yang juga telah diindentifikasi sebagai kontributor penting terhadap kepuasan pada riset yang dilaksanakan di Jerman (Yavas et.al, 2004) dan Uni Emirat Arab (Jamal \& Naser, 2002). Riset ketidak puasan juga telah dilaksanakan bagi pelanggan perusahaan jasa financial yang tidak puas dengan call center telah diidentifikasi di Amerika (Feinberg et.al, 2002), sebagaimana juga pelanggan banking elektronik di Inggris (Joseph et.al, 2005) dan pelanggan bank di Belgia (Bloemer et.al, 2002).

Telah diketahui bahwa pelanggan yang puas berdampak terhadap persaingan merek (Oliver, 1991); yakni hanya customer perusahaan yang bisa dipercaya adalah pelanggan yang loyal. Satu studi tentang persepsi pelanggan atas kualitas jasa dan sikap mode jasa yang diberikan (teller \& ATM), di Inggris menemukan bahwa para pelanggan ini secara positif berhubungan dengan kepuasan, yang pada gilirannya berhubungan positif dengan loyalitas (Moutinho \& Smith, 2000).

Upaya ini telah menemukan bahwa beberapa pelanggan bank di Inggris membutuhkan lampiran positif dan ikatan sosial dengan bank dari para pelanggan ini (Aldlaigan \& Buttle, 2005). Naturalitas yang kuat dari loyalitas effektif dan cognatife seperti yang disampaikan oleh Oliver (1999) diuji dalam studi internet yang menjelaskan (mengkorfirmasikan), vulnerabilitas customer loyalitas-cognitif terhadap bank yang menggantikan (Pedersen \& Nysveen, 2001). Kedua peneliti tersebut menemukan bahwa pelanggan bank loyal-cognitif lebih dipengaruhi oleh akses jasa belanja berbasis agen internet yang dikenal sebagai "shopbots" dari pada yang bersifat loyal affective dan cognitive. Langkah nyata selanjutnya dalam riset marketing perbankan adalah studi mengenai komunitas konsumsi, karena loyalitas terhadap lembaga financial adalah mengakar, tidak hanya pada merek, tetapi juga relatif teman-teman sejawat, dan tetangga dari para pelangganya. Oliver (1999) menjelaskannya dengan mengacu pada organisasional seperti "pedesaan".

Institusi keuangan secara potensial dapat mengambil keuntungan dari mempromosikan kepekaan komunitas. Meningkatkan keterlibatan konsumen dengan produk perusahaan adalah alat untuk mendorong loyalitas customer (Quester \& Lym, 2003) dan kualitas hubungan antara seorang customer dengan penyedia jasa financialnya berhubungan dengan kecenderungan untuk mengganti lembaga keuangan (Chakravarity, et.al, 2004). Dengan demikian dengan cara mendorong kepekaan komunitas sebuah perusahaan dapat meningkatkan keterlibatan consumer 
dalam produknya serta memperkuat hubungan antara customer dengan perusahaan tersebut.

Literatur ini diuji untuk menentukan komponen-komponen yang bisa diamati terhadap kepekaan komunitas antara customer-customernya untuk menjelaskan skala komunitas jasa financial. Ini diikuti oleh seleksi frame sample customer lembaga keuangan. Data survei dari vaiabel-variabel yang diamati kemudian dinalisa untuk memperoleh definisi konspetual. Perkiraan dari kekuatan kepekaan komunitas responden dilaksanakan dan implementasi temuan-temuan terhadap praktek marketing dala industri didistribusikan.

\section{Komunitas}

Dugaan bahwa para consumer membentuk komunitas yang menentukan dirinya menurut merek produk yang dipakai telah dijelaskan oleh Boorstin (1973). Banyak konsumen mengembangkan kepekaan komunitas dengan penyedia jasa yang dirasakan oleh konsumen khususnya sehingga menjadi tergantung (dependable), kompeten dan kepercayaan (Goodwin, 1986).

Kesamaan adalah benar bahwa konsumen yang menemukan barang-barang yagn dipercayanya untuk mendorong ketertarikan dan kemampuan fisiknya sebagai pembuat homemaker (Fournier, 1998). Study persepsi komunitas juga ditemukan dalam riset yang dilaksanakan dalam ilmu sosial (Glynn, 1981: Puddifoot, 1995). Upaya-upaya ini membentuk literature yang relevan untuk mengkoseptualisasi dan mengkonstruksi komunitas antar konsumen.

\section{Komunitas Konsumsi}

Orang yang berimigrasi ke Amerika pada abad 19 menyatu dengan imigrant-imigrant lain dengan entitas dan nasionalitas yang sama (Boorshin, 1973). Karena budaya konsumsi masa menghasilkan barang-barang yang dikembangkan oleh komunitas konsumen ini mulai menyatu dengan yang lain dalam hal barangbarang yang mereka beli dan mereka gunakan.

Komunitas ini mungkin terbentuk oleh teknologi baru seperti mesin jahit, yang memungkinkan produksi massa dengan pakaian yang siap pakai. Perusahaanperusahaan peneima jasa penghantaran seperti sears dan perkenalan terhadap rural free delivery yang memungkinkan distribusi luas dari barang-barang produksi masa. Perluasan dimana consumer dapat menyatu dengan yang lain menggunakan produk yang sama disebut "komunitas" (Oliver, 1999).

Komunitas konsumen memberikan struktur dukungan sosial dalam hal pemakai sebuah produk bermerek dapat mempersatukan satu sama lain dalam hal komitmen mereka terhadap merek. Sistem dukungan ini membendung serangan ketidakcocokan kognitif setelah pembelian sautu produk. Sosialisasi dalam kelompok tersebut akan memfasilitasi resolusi terhadap kegagalan produk atau jasa, atau bahkan mencegah kegagalan produk atau jasa yang akan terjadi. Semua elemen-elemen ini dapat diharapkan menjadi bagian dari hubungan antara konsumen dengan penyedia jasa financialnya. 


\section{Persahabatan (Camaraderie)}

Friedma et.al (1993) menguji konsep komunitas konsumsi yang menemukan bukti empiris yang lemah dari dugaan dua kelompok sarjana yang mendaftar untuk program MBA. Studi-studi "orang-orang gunung" (Belk dan Costa 1998) dan Harley Davidson Owner (Schouten \& McAlexander, 1995) telah mengkontribusikan bukti etnografi sub culture komunitas konsumen. Pengujian hubungan antara customer dan merek seperti Ford Bronco dan Saab Automobile menjelaskan konsep komunitas merek. Keduanya dalam ketetanggaan (hubungan dan lingkungan bermediasi komputer (Muniz dan O'Guinn, 2001).

Mengelaborasi terhadap ikatan antara customer, customer dengan merek, serta customer dengan produsen merek McAlexander et.al (2002) mengindentifikasi integrasi elemen-elemen ini menjadi sebuah komunitas merek. Integrasi komunitas merek juga ditemukan berhubungan positif terhadap kepuasan dan loyalitas customer judi kasino (McAlexander, et.al, 2003). Secara sama dalam sebuah survei customer bank di Iniesta \& Sancez-Spanyol (2002) mengidentifikasikan susunan manifest komitmen, yang mereka anggap sebagai tindakan yang diambil untuk menunjukkan kesungguhan untuk mengembangkan hubungan yang stabil, atau keinginan untuk melakukannya.

Dalam riset ini, kepekaan terhadap keanggotaan dalam komunitas konsumsi yang berbasis merek diilustrasikan dengan persahabatan "camaraderie". Dalam hal ini camaraderie ditandai dengan ikatan umum dan sosialisasi antara teman, relative dan teman sejawat yang merupakan anggota komunitas konsumsi, seperti halya civic, sosial dan organisasi komunitas. Para anggota komunitas konsumsi seringkali memperkenalkan teman-temanya kepada kelompok mereka (item-item questioner terlampir dalam appendix).

Dalam sejumlah setting riset telah menemukan bahwa hubungan jasa dapat menghasilkan ikatan khusus antara penyedia jasa dan konsumen. Misalnya, hubungan personal antara customer dengan pegawai bank memfasilitasi ikatan kepercayaan yang memperkuat hubungan antara customer dengan bank (Gounaris, et.al, 2003).

Hal ini nampaknya karena fakta bahwa customer menganggap "persahabatan \& kesopanan" sebagai atribut jasa bank yang paling penting (Oppewal \& Vriens, 2000). Dalam studi kasus yang mendalam tentang hubungan antara konsumen dan merek mereka menentukan bahwa hubungan tersebut akan menghasilkan personifikasi yang sangat tinggi terhadap produk bermerek (Fournier, 1998). Hubungan tersebut biasanya merupakan hasil keterikatan peningkatan atas barang-barang yang membuat konsumen "kelihatan" baik (yakni kosmetik, pembersih, produk-produk makanan). Istilah yang digunakan untuk menjelaskan hubungan ini adalah "friendship-persahabatan", "Courtship" dan "secret affairs".

Dalam jasa financial bisa menjadi satu produk yang paling mudah untuk dipersonifikasikan, interaksi ekstensif yang sudah ada antara customer dan personil bank dalam menjalankan fungsi-fungsi seperti pembayaran dan penerimaan serta peminjaman. Dugaan ini dikonfirmasi pada sebuah study tentang customer bank bernilai jaringan tinggi dimana dua dari pengukuran paling penting dalam hal kualitas jasa adalah "perhatian terhadap kebutuhan bank" dan "hubungan mudah dan 
frekuwentif" (Lasser, et.al, 2000). Study etnografis menemukan bahwa sentimen terhadap solidaritas dan camaraderie berkembag dalam hal sulitnya perjalanan melalui percepatan (Arnould \& Price, 1993). Ketika produk adalah jasa yang secara khusus dikaksanakan dengan benar, konsmen akan menjalin hubungan dengan penyedia jasa. Istilah yang digunakan (Goodwin, 1996) untuk menggambarkan hubungan ini adalah komunalitas.

Dengan demikian, komunitas dapat dicapai dalam konteks barang dan jasa. Perbedaan antara komunitas dengan komunalitas adalah bahwa komunalitas merupakan kepekaan rasa persahabatan antara seorang konsumen dengan seorang pegawai penyedia jasa. Karakteristik komunalitas dan komunitas konsumsi mencakup tidak hanya persahabatan dengan pegawai perusahaan jasa financial, tetapi juga dukungan terhadap perusahaan (organisasi) non profit serta menghadiri event-event yang disponsori oleh salah satu penyedia jasa keuangan.

\section{Persepsi Komunitas}

Terdapat ketertarikan penting dalam ilmu sosial dalam studi konseptual komunitas. Arahan riset yang relevan adalah kepekaan komunitas psikologikal (misalnya Glyn, 1981) dimensi identitas komunitas (Puddifoot, 1995), dan modal sosial (Putnam, 2000). Upaya-upaya yang membagi kesamaan komunitas dalam setiap setting riset dimana orang hidup dan bekerja.

Dari upaya exploratory yang mulai dengan intument survey yang mencapai hampir 150 pertanyaan, Glynn (1981) mengambil 60 item. Kepekaan skala komunitas psikologikal item yang paling penting dari instrument adalah jumlah tahun yang responden harapkan untuk tetap menghidupkan komunitas, disamping kegunaannya yang didesak oleh lamanya. Nasar \& Yulian (1995) melaksanakan versi singkat skala Glynn untuk mempelajairi kepekaan komunitas dalam ketetangaan yang beragam. Mereka menemukan bahwa kepekaan komunitas secara positif berhubungan dengan jumlah tetangga yang dikenal, dan jumlah tetangga yang merupakan teman.

Studi yang sama (Catano, et.al, 1993; Davidson \& Cotter, 1997) yang menjalankan skala Davidson \& Cotter (19986) memperoleh hasil-hasil yang tercampur. Sementara Catano, et.al (1993) hanya dapat menghubungkan kepekaan komunitas terhadap kesamaan memenuhi keluhan terhadap union. Davidson \& Cotter (1997) menemukan hubungan antara kepekaan yang kuat terhadap komunitas dan pembaca surat kabar. Upaya lain yang menjalankan versi Italia dari skala Davidson \& Cotter yang menemukan bahwa penduduk dari komunitas yang kecil lebih puas dengan kehidupan dalam komunitas mereka (Prezza \& Constantini, 1998).

Juga telah dijelaskan bahwa para pegawai tidak bisa"tahu setiap orang". Ketika jumlah teman sejawatnya meningkat 100 (Gladwell, 2000). Temuan yang sama diperoleh dalam study perbandingan dua dua tim olah raga profesional (Fisher \& Wakefield, 1998). Mereka terkejut, menemukan bahwa fans dari tim dengan catatan kalah/menang yang tidak sukses lebih loyal dari pada tim yang tidak sukses lebih loyal dari pada tim yang sukses. Para fans merasa partisipasi aktif dalam 
kemunitas melalui klinik \& anggota tim pelayanan publik melalui kewarganegaraan yang baik menjadi lebih penting dari pada record kewenangan/kekalahan mereka.

Putnam (2000) mempelajari kepekaan komunitas yang dia istilahkan sebagai "modal sosial". Modal sosial digambakan dengan interaksi sosial homogenitas \& heterogenitas untuk memecahkan masalah dan meningkatkan hidup dalam komunitas. Untuk menaksir keadaan modal sosial yang dia formulasikan sebagai index modal sosial dan menjalankan analisa rangkaian watu keterkibatan dan partisipasi komunitas.

Putnam menemukan bahwa modal sosial telah menurun dari pertengahan tahun 60-an hingga akhir 90-an, dan memberikan saran-saran untuk menghidupkan lagi modal sosial. Komponen index meliputi keyakinan dalam hal kepercayaan dan kejujuran kemanusiaan, dan keinginan untuk berpartisipasi dalam organisasiorganisasi civic \& non profit (lihat appendix). Catatan bahwa terdapat tingkatan overlap (yang melebihi) antara camaraderie dan komunitas dalam literatur marketing serta beberapa komponen modal sosial dalam riset kebijakan publik (Putnam, 2000).

\section{Ekspektasi Riset}

Riset ini merupakan upaya pertama yang menentukan apakah kepekaan komunitas sebagaimana yang dirasakan oleh customer lembaga keuangan yang bisa diukur. Ini juga merupakan upaya pertama untuk mengkuantifikasikan sikap customer terhdap lembaga financial mereka dalam konteks keanggotaan dalam komunitas konsumsi. Sebagaimana dinyatakan diatas sangat sedikit literatur bank yang telah menjelaskan variabel-variabel dan konstruk yang dapat diterima untuk mengukur kepekaan komunitas. Sebab itu, riset ini sepenuhnya bergantung pada temuan-temuan riset konseptual (Goodwin, 1996), studi kualitatif (Fournier,1998; Schouten \& McAlexander,1995), dan riset kuantitatif (Friedman, et.al, 1993) di luar industri jasa financial, sebagaimana studi-studi empiris jasa financial (Aldlaiqan \& Buttle, 2005; Gounaris, at.al, 2003; Jamal \& Naser, 2002).

Orang yang merasa dirinya anggota komunitas menikmati semangat persahantan antar kelompok mereka. Bukti perasaan kepemilikan terhadap sebuah kelompok terhadap semangat yang diperoleh Belk \& Costa (1998). Friedman et.al. (1993) mengidentifikasi pola konsumsi yang lama antara mahasiswa MBA, dan Schouten \& McAlexander (1995) menggali subculture konsumsi pemilik Harley Davidson, yang konsisten dengan dugaan-dugaan ini.

Pla. Sebuah kepekaan yang dirasakan terhadap camaraderie berhubungan positif dengan kepekaan tehadap keanggotaan dalam sebuah komunitas konsumsi.

Beberapa lembaga keuangan pada dasarnya dilaksanakan oleh komunitas yang berdekatan (close-knit). Misalnya lembaga-lembaga keuangan kota kecil lebih mengacu kepada bank komunitas. Perbedaan antara customer dengan cakupan nasional dan bank-bank komunitas ditemukan dalam profiles demografik customer dan minat mereka terhdap atribut pelayanan bank (Kaynak \& Harcar, 2005). Beberapa unit kredit dijalankan oleh "komunitas"individu yang membagi ikatan 
yang sama (common bond), seperti keanggotaan gereja, pegawai atau anggota sebuah asosiasi professional.

Sama pentingnya adalah manfaat terhadap penyedia jasa keuangan dari kepekaan yang dirasakan terhadap komunitas customernya. Putnam (2000) cenderung menyebut benefit ini sebagai "model sosial". Benefit sosial dari model sosial meliputi sosialiasasi, tingkah laku altruistic, kepercayaan, dan keyakinan diri manusia. Bukti keinginan terhadap sosialisasi dalam konteks customer-banker contex diperoleh dari minat peserta survei untuk menjalankan bisnis dengan bank mereka secara perorangan (Howcroft, et.al, 2002). Modal sosial dirasakan oleh anggota komunitas sebagai benefit keanggotaan dalam kelompok.

Plb. Modal sosial secara positif berhubungan dengan kepekaan anggota dalam komunitas komsumsi

Upaya-upaya yang dapat diterima oleh perusahaan jasa financial meliputi dukungan budaya, amal, event-event atletik dan meeting/bareque tahunan unit kredit. Dari semua element modal sosial yang paling krusial terhadap industry jasa financial adalah kepercayaan,dan hubungan eratnya dengan dimensi asuransi kualitas jasa (Lasser, et.al, 2000). Pada P1b juga memuat rating yang cukup tinggi terhadap budi baik (coustesy), kredibilitas, empati, dan keadilan oleh customer bank (Allred \& Adams, 2000).

Karakteristik ketiga dari komunitas konsumsi adalah komunalitas. Dalam riset ini, komunitas meliputi konteks hubungan customers dengan penyedia jasa (Goodwin, 1996). Juga dianggap ditemukan dalam hubugan antara customer dan produk yang sangat reliable dan dependable (Fournier, 1998). Bukti komunitas juga ditemukan dalam ikatan sosial positif yang memberikan level nilai relasional yang tinggi (Aldlaiqan \& Buttle, 2005). Hubungan personal antara customer \& pegawai juga bisa memfasilitasi ikatan kepercayaan yang memperkuat hubungan customer bank (Glounaris, et.al, 2003). Dimensi relasional kualitas jasa ditemukan satu atau dua pemicu kepuasan pelanggan.

Plc. Komunitas berhubungan positif terhadap kepercayaan keanggotaan dalam komunitas konsumsi

Banyak bank yang direputasikan menjadi pendukung yang hati-hati terhadap tujuan yang berguna dalam komunitas mereka. Contohnya seperti dukungan terhadap simfoni orchestra, palang merah, dan beasiswa yang diberikan kepada mahasiswa. Persyaratan regulatory memberi dapat manfaat terhadap hubungan komunalitas antar unit kredit dan anggota dewan direksinya, yang harus melayani kompensasi uang.

Fondasi teoretis camaraderie yang telah diuraikan sebelumnya, telah ditemukan dalam psikologi \& literature marketing; teori ini telah memberikan penjelasan bahwa anggota komunitas dengan kepekaan kepemilikan dengan kepekaan kepemilikan terhadap group yang unik mempunyai hubungan. Modal sosial akan membentuk jembatan yang menghubungkan antara anggota-anggota kelompok heterogen yang memberikan manfaat sosial yang sinergistik (Putnam,2000). Komunitas ini menjelaskan bahwa ikatan hubungan antara 
pelanggan dengan pegawai penyedia jasa financial dalam kelompok. Dalam kerja exploratory ini, ketiga element tersebut telah dianggap cukup untuk mengukur kepekaan komunitas dalam konteks jasa financial.

Pld. Camaraderie, modal sosial dan komunitas merupakan skala pengukuran unidimensional kepekaan komunitas konsumsi

Ekspektasi ini komitmen dengan literature (Prezza dan Constantini,1998; Davidson \& Cotter,1986). Tetapi ini juga penting untuk mencatat bahwa paling tidak satu kepekaan unidimensional skala komunitas disusun pada empat variabel yang telah dijalankan (McAlexander et.al, 2003), dan upaya lain untuk mengembangkan susunan konstruksi lapis pertama yang dijelaskan dalam 13 variabel yang diamati (McAlexander et.al, 2002).

Riset yang membandingkan kepekaan komunitas antar penduduk kota dengan ukuran yang berbeda di Italy adalah bahwa kepekaan komunitas antara responden wanita lebih kuat dari pada pria (Prezza dan Constantini,1998) (4). Tidak ada upaya yang dijalankan untuk mengukur perbedaan dalam kepekaan yang dirasakan terhadap komunitas konsumsi antar genders. Tetapi riset yang telah dijalankan yang menjelaskan sikap-sikap dan keyakinan wanita yang mengindentifikasikan adanya perbedaan relevan vis-à-vis pria. Riset sumber daya manusia telah mendokumentasikan pemisahan kerja oleh gender di bank besar Amerika (Hunter, et al., 2004).

Sebuah survei majalah keuangan menemukan bahwa pelajar SMA wanita mengungkapkan lebih sedikit rasa percaya diri yang berhubungan dengan pengetahuan mereka tentang isu-isu financial dan kemampuan mereka untuk mengelola uang dari pada pelajr prianya (Rock, 2005).Wanita lajang (single) lebih jarang/sedikit yang menggunakan pembayaran tagihan otomatis dan jasa telepon bank (Kolodinsky,et.al, 2004). Paling tidak, satu survei pelanggan bank menemukan bahwa wanita lebih erat hubungannya dengan ucapan-ucapan positif dan komitmen (Yavas, et al, 2004). Wanita juga nampaknya menjalankan bisnis dengan bank lokal dari pada bank nasional (Kaynak \& Harcar, 2005). Fournier (1998) secara sepesifik menjelaskan adanya hubungan personal yang intens antara wanita produk favoritnya.

Bukti empiris menjelaskan bahwa hubungan antara wanita dan lembaga keuangan berbeda dari pada yang dialami oleh pria. Maka penulis artikel ini menyimpulkan bahwa :

P2.Wanita memiliki kepekaan komunitas yang lebih kuat terhadap lembaga keuangan dari pada pria.

\section{METODE RISET Skala Dalam Questioner}

Dalam riset ini, skala item-11 telah dikembangkan. Komponen penting dari kepekaan komunitas adalah camaraderie yang mengetengahkan pentingnya hubungan antar customer (Friedman,et.al, 1993:Schounten \& McAlexander,1995), dan hubungan antara pelanggan dengan penyedia jasa. Item-item yang menjelaskan camaraderie meliputi pertanyaan pertama, kedua, ketiga, keempat dan ketujuh (lihat 
appendix). Jika seorang individu merasa bahwa keanggotaan dalam sebuah organisasi itu penting bagi mereka (item tujuh), nampaknya mereka lebih merasa bahwa kepekaan keanggotaan dalam hubungannya dengan penyedia jasa keuangan, mungkin karena kekhususan atau atribut unik institusi (item3).

Individu yang mengabdikan sosialisasi waktu dengan teman-teman mereka (item 4) juga nampaknya akan memikirkan hubungan mereka dengan penyedia jasa financialnya sebagai keanggotaan dalam sebuah komunitas, khususnya jika temannya yang juga customer dari lembaga yang sama (item 2). Beberapa customer mungkin saja termotivasi untuk mendukung teman, kerabat, dan teman sekerjanya untuk bergabung dengan mereka sebagai customer (item 1). Item 5 dan item 6 adalah secara harpiah (verbatim) dari indeks modal sosial (Putnam, 2000), yang menjelaskan kesetiaan manusia. Pertanyaan 8 s/d 11 dapat diterapkan pada komunalitas.

Semua item skala dalam artikel ini jabarkan dengan 5 (lima) skala poin dari "sangat tidak setuju hingga sangat setuju".Questioner dalam artikel ini juga berisi 8 (delapan) item yang menangkap informasi demografis respondents dan 86 item untuk memperoleh data pada upaya-upaya riet ini.

\section{Sample Frame}

Dua kelompok di Texas Selatan diminta untuk melengkapi questioner yang diatur sendiri; mahasiswa bisnis administrasi yang mengikuti kursus singkat di sekolah (universitas) umum, dan pengunjung (pelanggan) mall. Tempat (venue) ini dipilih karena dapat memberikan contoh individu dari wilayah demografis yang luas serta menyediakan sample heterogin dalam hal usia, pendidikan dan pengalaman sebagai customer jasa keuangan.

Riset ini melengkapi upaya-upaya yang diterbitkan pada decade ini seperti Rostock; Jerman, Yunani,Uni Emirat Arab, Belgia dan New Zealand. Siswa para peserta diminta untuk merespon questioner,baik pada permulaan atau akhiran dari pertemuan kelas regular (pada opsi dalam struktur); Metode intercept dimanfaatkan dipusat pembelanjaan, bahwa kelompok telah diminta merespon terhadap questioner dalam konteks penyedia jasa financial (Primary Financial Services Provider=PFSP).

Total 505 questioner didistribusikan dan dikembalikan, dimana $330(65 \%)$ questioner telah diisi lengkap. Analisis dalam bentuk survey dengan data hilang, telah menentukan alasan utama untuk tidak menjawab pertanyaan yaitu :

a. Tidak adanya hubungan account dengan penyedia jasa financial;

b. Kurang sabar karena panjangnya instrument survey;

c. Ketidak inginan merespon item-item questioner spesifik;

Dalam hal ini, data yang hilang tidak akan diestimasi. Selanjutnya dalam artikel ini juga dijelaskan bahwa 30 responden merupakan kelompok heterogen. Hampir 96\% (318) responden yang tinggal dalam jarak 100 mil dari dua loksai dimana survey dilakukan. Sebanyak $8(2,4 \%)$ responden berasal dari luar area, dan empat kelompok individu lainnya tidak menjelaskan domisili mereka. Remaja dewasa (18 s/d25 tahun) berjumlah 51,8\%atau 171 responden; dan $27 \%$ atau 89 responden berusia antara $25 \mathrm{~s} / \mathrm{d} 35$ tahun, sebanyak 17,9\% atau 59 responden 
berusia $35 \mathrm{~s} / \mathrm{d} 55$ tahun, sedangkan responden yang berusia $55 \mathrm{~s} / \mathrm{d} 65$ tahun berjumlah $2,1 \%$ atau 7 orang, dan sisanya dua orang responden berusia 65 tahun.

\section{ANALISA DAN PEMBAHASAN \\ Analisis Result-Exploratory}

Riset exploratory ini merupakan pengujian pertama dalam hal kepekaan pelanggan bank terhadap komunitas konsumsi. Analisis keseluruhan dibutuhkan untuk menaksir validitas convergen dan exploratory untuk menentukan apakah variabel yang diamati menjelaskan kepekaan terhadap kontruk komunitas. Analisis inisial dari matriks komponen telah menjelaskan bahwa 10 variabel pengamatan terdiri atas tiga faktor dengan eigen values yang lebih besar dari pada satu, dengan berat yang signifikan pada gambar 3 variabel cross loading atas dua faktor. Variabel ke-8 (menghabiskan waktu bersama teman) tidak member analisis faktor yang dijalankan dengan mengggunakan sis variabel. Hasilnya adalah solusi dua faktor, dengan tiga variabel secara signifikan loading atas kedua faktor.

Croanbach's alpha 0,80 dihitung untuk menentukan realibilitas 10 skala item, yang comparable dengan kepekaan atas riset komunitas seperti 0,82 yang diperoleh oleh Prezza dan Constantini (1998) dan 0,70 yang dilaporkan oleh Davidson dan Cotter (1997). Analisis ini memberikan bukti bahwa dua faktor kepekaan skala komunitas konsumsi valid \& reliable, sekalipun dengan kontribusi ambique oleh variabel yang mengukur perluasan dimana responden, yakin bahwa teman sejawat menjalankan bisnis dengan penyedia jasa financial mereka (lihat Table 1).

Table 1. Final Scale Items

\begin{tabular}{|c|l|l|ll|}
\hline $\begin{array}{c}\text { Item } \\
\text { No }\end{array}$ & \multicolumn{1}{|c|}{ Measurement Item } & Aspect of Communitty & \multicolumn{2}{|l|}{ Factor Loading } \\
One & Two \\
\hline 1 & $\begin{array}{l}\text { Being a member of a } \\
\text { civic, social, or } \\
\text { community organizational } \\
\text { is important to me }\end{array}$ & S.C., Camaraderie & 0,718 & 0.460 \\
\hline 2 & $\begin{array}{l}\text { Performing volunteer } \\
\text { workis important to me }\end{array}$ & S.C., Communality & 0.711 & 0.496 \\
\hline 3 & $\begin{array}{l}\text { Financially supporting } \\
\text { non profit organizations is } \\
\text { important to me }\end{array}$ & S.C., Communality & 0.701 & 0.287 \\
\hline 4 & Most people are honest & Social Capital & 0.687 & 0.641 \\
\hline 5 & $\begin{array}{l}\text { Most people can be } \\
\text { trusted }\end{array}$ & Social Capital & 0.651 & 0.682 \\
\hline
\end{tabular}

Note : "Response format for all items: 1 Disagree to 5 Agree

\section{Analisis Result-Confirmatory}

Analisis faktor confirmatory dijalankan dengan menggunakan AMOS 4.0. Model pengukuran menggunakan grafik AMOS. Konstruk pertama disebut 
"camaraderie \& communality". Variabel yang relevan adalah delapan items yang mempertahankan analisis faktor exploratory. Keanggotaan dalam civic/sosial/organisasi komunitas, menjelaskan bahwa bisnis dengan lembaga sebagai keanggotaan dalam kelompok khusus yang menjalankan kerja sukarela, mendukung organisasi non profit.

Kehadiran pada event-event lembaga sponsor, pegawai lembaga keuangan yang oleh customer dianggap sebagai teman. Keinginan untuk merekomendasikan lembaga keuangan kepada teman, serta melakukan bisnis pada lembaga yang sama sebagai satu pertemanan. Konstruk lain yang disitilahkan sebagai "social capital" terdiri atas 2 variabel. Sentiment bahwa orang jujur dan bisa dipercaya.Analisis menjelaskan bahwa lima dari delapan variabel camaraderie \& komunalitas memiliki variant error. Kasus Heywood (Kline,1998) kepada level yang sangat rendah (yakni0,005) prosedurnya biasanya tidak berhasil.

Hasil dari konstruk yang kedua (second-order) terdiri dari 2 konstruk order pertama (lihat Figure 1) dengan penyesuaian model yang baik : GF1 = 0,968; dan AGFI $=0,921$. Selanjutnya pengujian statistik dengan Chi-Square menghasilkan $(28,076(\mathrm{df}=6), \mathrm{p}=0,000$, Chi-Square/df=0,469), yang disebabkan oleh besarnya responden (dalam riset ini 330, tetapi dengan 200 responden saja biasanya sudah memadai). Reliabilitas kontruk $(0,763)$ memuaskan, dan extraxt variant $(0,408)$, sedikit kurang dari yang diinginkan (Hair, et.al, 1995). Maka hal ini merupakan riset pertama yang memformulasikan kepekaan konstruk komunitas konsumsi customer industry jasa yang membuktikan validits dan reliabilitas konstruk.

Secara khusus, pengukuran camaraderie dan communality menjelaskan pentingnya keanggotaan civic/social, organisasi komunitas, menjalankan kerja sukarela, dan mendukung organisasi non-profit. Hasil ini hanya secara parsial mendukung P1a, karena hanya satu variabel camaraderie dari 5 item asli yang bertahan dalam analisis. Sama halnya P1c juga hanya secara terpisah mendukung; meskipun komunalitas mengkonstribusikan 2 item terhadap konstruk, dua yang lain ditolak karena tidak valid (invalid). Konstruk modal sosial menjelaskan interaksi. Konstruk modal sosial menjelaskan interaksi sosial kelompok untuk memecahkan masalah dan meningkatkan kehidupan dalam komunitas. Kedua pengukuran modal sosial mempertahankan analisis konfirmatory, sepenuhnya mendukung P1b.

P1d mengkhususkan bahwa kepekaan konstruk komunitas bersifat uni dimensional, hipotesisnya tidak didukung oleh hasil penelitian. P2 menjelaskan bahwa wanita merasakan kepekaan komunitas yang lebih besar, konsisten dengan risetnya Prezza dan Constantini (1998) dan Kaynak \& Harcar (2005). P2 diuji dengan menggunakan faktor scores terhadap konstruk first-order camaraderie \& communality.

Analisis variant dilaksanakan untuk 3 skala. Konstruksi modal sosial menjelaskan bahwa terdapat perbedaan yang signfikan antara persepsi keanggotaan komunitas responden wanita dan pria ( $\mathrm{p}=0,803$ dan 0,074$)$. Maka P2 tidak didukung, berarti temuan ini kontradiktif dengan riset sebelumnya. Tetapi signifkansi sikap yang lebih positif yang berhubungan dengan modal sosial antara pria yang sangat menarik. 


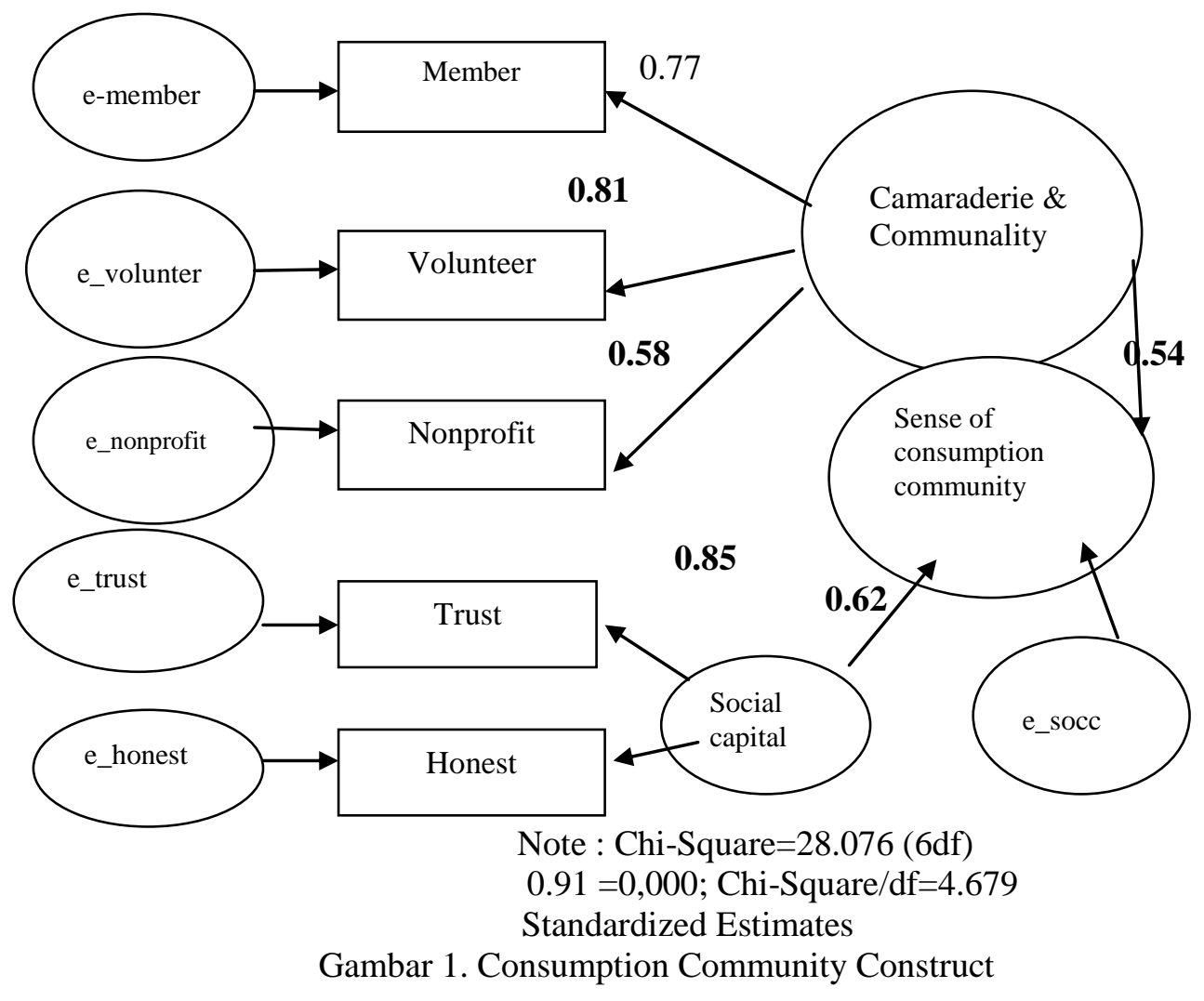

\section{Komunitas Konsumsi dan Anggotanya}

Nampaknya teori tidak menjelaskan hubungan antara kepekaan komunitas \& karakteristik responden lain. Ditribusi data untuk masing-masing skala kemudian dianalisis dengan ukuran mean, median dan modus dari skala camaraderie \& communality adalah 10,12,10 dan 9,00 - secara respektif (kisaran kemungkinan nilai antara $3 \mathrm{~s} / \mathrm{d} 15)$.

Data dengan koefisien kemiringan $(-0,279)$ dengan kurtosis yang sangat kecil $(-0,397)$. Untuk skala modal sosial dengan mean, median dan modus adalah 5,34; 6,00; dan 6,00 dengan kisaran kemungkinan nilai dari 2 s/d 10. Terdapat kemiringan positif yang kecil $(0,214)$ dan distribusi data lebih datar dari normal (kurtosis-0,795). Terakhir, mean, median dan modus kepekaan terhadap skala komunitas konsumsi adalah 15,46' 15 dan 15 untuk kisaran kemungkinan skor 5 s/d 25 .

Distribusi data sangat dekat dengan normal (kemiringan 0,005 dan kurtosis0,072). Dengan demikian, terdapat perbedaan dalam kepekaan yang dirasakan terhadap komunitas konsumsi diantara customer lembaga keuangan. Distribusi nonpeak tipis dibuktikan dengan statistik kurtosis negatif, sejumlah besar responden memiliki persepsi positif yang kuat dari komunitas konsumsi antara pelangganya, dan nampaknya terdapat perbedaan sistematis antara peserta survei. 
Paling tidak, satu studi menemukan bahwa customer bank yang nampaknya puas adalah mereka yang berusia 55 tahun (Bloemer, et.al, 2002). Riset lain telah menemukan bahwa usia secara negatif berhubungan dengan kecenderungan pindah ke bank lain (Chakravarty, et.al, 2004). Apakah kebenaran yang sama terhadap kepekaan komunitas? Analisis variant terhadap kontsruk modal sosial menemukan bahwa terdapat peningkatan signifikan dalam persepsi positif komunitas antara kelompok yang berumur 18 tahun hingga 25 dan 26 tahun hingga 35 dan 36, serta 55 hingga 65 tahun dan diatas 65 tahun $(\mathrm{p}=0,042)$. Skor mean untuk kelompok ini adalah 5,24;5,17;5,58;7,43 dan 8,00. Catatan bahwa skor mean untuk responden antara usia 18 s/d 55 tahun menjelaskan bahwa terdapat tingkatan tipis ketidak setujuan dengan gagasan bahwa "kebanyakan orang jujur", bisa dipercaya".

Hasil ini memberikan validitas external terhadap gagasan bahwa customer yang tidak puas sering tidak pindah (Bloemer, et.al, 2002; Pather \& Farguhur, 2004; White \& Yamandrain, 2004). Apakah ada hubungan positif antara persepsi keanggotaan dalam komunitas konsumsi \& hubungan yang lama dengan penyedia jasa financial seseorang? Analisis variant menjelaskan bahwa ini bukanlah kasus untuk modal sosial $(\mathrm{p}=0,067)$, camaraderie \& communality $(\mathrm{p}=0,195)$, dan konstruk komunitas konsumsi $(\mathrm{p}=0,149)$. Plot mean kepekaan komunitas konsumsi memberikan skor terhadap ke,ompok yang tahan lama yang menghasilkan bentuk $\mathrm{U}$ untuk hubungan dua vaiabel (U-shaped relationship between the two variables).

Peserta survei yang menjalankan bisnis dengan penyedia jasa financialnya kurang dari satu tahun, dari pada dua tahun melaporkan kepekaan yang lebih kuat terhadap keanggotaan dalam komunitas konsumsi dari pada responden dengan hubungan yang lebih lama antara satu sampai dua tahun. Dalam riset ini, tidak ada perbedaan signifikan antara customer bank, unit kredit dan perusahaan investasi terhadap modal sosial $(\mathrm{p}=0,741)$, camaraderie dan communality $(\mathrm{p}=0,209)$, dan skala kepekaan komunitas konsumsi $(\mathrm{p}=0,313)$.

\section{DISKUSI DAN IMPLIKASI MANAJERIAL Diskusi}

Upaya ini memberi kontribusi terhadap study tingkah laku konsumen dengan memperluas riset sebelumnya untuk memicu kepekaan utama terhadap skala pngukuran komunitas konsumsi bagi lembaga keuangan.Analisis sebelas item menghasilkan dua dimensi: camaraderie \& communality dan modal sosial (Barry, 2002).

Juga interest adalah disposisi enam variabel yang tidak berkontribusi terhadap kepekaan komunitas konsumsi. PFSP mereka terhadap temannya merupakan bagian dari konstruk. Dapat menerangkan bahwa untuk memperoleh rekomendasi lembaga keuangnan harus memberikan customer dengan hadiah yang berwujud. Dugaan bahwa customer membagi PFSP kepada temannya yang tidak valid. Ini disebabkan karena lemahnya pengetahuan responden survei. Kemungkinan lainnya adalah bawa bentuk camaraderie ini tidak berarti bagi customer lembaga financial, maka promosi untuk hal ini tidak akan efektif.

Nampaknya bahwa dua variabel modal sosial tidak berkontribusi terhadap kepekaan komunitas konsumsi. Menghadiri event-event yang disponsor oleh PFSP 
(item 9) gagal berkontribusi terhadap konstruk. Berarti bahwa lembaga keuangan yang mensponsori pertunjukan seperti opera, atau simfoni serta mengiklankan keterlibatan mereka tidak akan mempromosikan perusahaan mereka. Sentiment perkawanan terhadap pegawai lembaga keuangan juga bukan merupakan komponen valid modal sosial dan kepekaan komunitas konsumsi.

Sebagaimana dinyatakan sebelunya, riset ini merupakan bahwa pria secara signifikan merasa lebih kuat ikatan sosial kepada PFSP mereka. Bertetangan dengan Prezza \& Constantini (1998) yang menemukan bahwa wanita memiliki rasa (kepekaan) komunitas yang lebih kuat. Paling tidak, ada satu studi yang sama yang juga memperoleh hasil-hasil yang berbeda; Iniesta \& Sanchez (2002) menemukan bahwa pasangan yang sudah menikah tetap dengan bank mereka karena mereka setuju melakukannya. Apakah wanita nampaknya lebih diintimidasi oleh lembaga keuangan karena manajemen lembaga suatu bank secara didominasi oleh pria. Bukti empiris menjelaskan bahwa manajemen suatu bank secara sistematis merestrukturisasi gambaran kerja guna memisahkan tugas-tugas kerja (Hunter, 2004).

Mengapa tidak ada perbedaan signifikan dalam persepsi afiliasi komunitas konsumsi menemukan bahwa antara customer bank, unit kredit dan perusahaan inevstasi?. Jawabannya mungkin ada dalam literatr ini. Riset terbaru menggali ketidakpuasan customer (Bloemer, at.al, 2002); Feinberg, et.al, 2002; Josep, et.al, 2005) dan paling tidak satu studi mencoba memprediksikan deteksi customer (Garland, 2002). Jelasnya terdapat trend dalam indsutri jasa keuangan yang dapat mempengaruhi kepuasan customer.

Di Eropa, rasionalisasi industri perbankan (Netlis at.al, 2000) telah menghasilkan konsolidasi bahwa di Amerika telah mempengaruhi sikap customer terhadap bank lokal dan bank nasional (Kaynak \& Harcar, 2005). Salah satu kemungkinan sebab ketidakpuasan dan disloyalitas adalah loyalitas kognitif yang menyebabkan hubungan customer bank dalam bahaya terhadap penggantian bank yang akan mengurangi biaya fee atau peningkatan dalam pertimbangan income hubungan (Pederson \& Nysvee, 2001).

Jawaban terhadap masalah loyalitas kognitif adalah meningkatkan hubungan customer lembaga (bank). Riset ini menekankan kebutuhan dengan menjalin manajemen hubungan (Jones \& Farquhar, 2003). Studi lain menjelaskan pentingnya ikatan sosial positif (Aldlaiqan \& Buttle, 2005) perhatian terhadap customer secara individual (Yavas, et.al, 2004), hubungan pribadi antara customer dan pegawai bank (Gounaris, et.al, 2003) dan dimensi relasional kualitas jasa (jamal \& Nazer, 2002).

\section{Implikasi Manajerial}

Riset marketing hingga saat ini tidak menjelaskan perbedaan dalam persepsi komunitas konsumsi antara bentuk-bentuk perusahaan dan/atau ketahanan hubungan customer. Tetapi hubungan minat ini terhadap praktisi, dan analisis post hoc variant dilaksanakan. Tidak ada perbedaan signifikan dalam persepsi komunitas konsumsi antara customer bank unit kredit, tabungan dan pinjaman, dan perusahaan sekuritas. Hasil yang sama diperoleh untuk hubungan antara persepsi komunitas konsumsi dan ketahanan hubungan customer. 
Para praktisi dalam bidang perbankan, unit kredit, thrift dan industri sekuritas, harus laki-laki dengan klaim yang customer mereka, yang nampaknya mengganggu hubungan yang erat dengan perusahaan mereka dari pada penyedia mereka disektor lain. Karena dukungan empirisnya yang lemah itulah sebabnya, maka tidak ada bukti dalam riset ini bahwa customer jangka-panjang memiliki hubungan yang dekat dengan PFSD mereka.

\section{Keterbatasan Studi}

Studi ini merupakan upaya exploratory pertama yang menguji dugaan kepekaan komunitas yang dirasakan oleh customer lembaga keuangan. Lima variabel dalam skala kepekaan komunitas tidak bisa dianggap sebagai definisi komprehensif kepekaaan komunitas. Riset lanjutan/tambahan perlu dilakukan untuk mengungkapkan atribut yang tidak dikenal dari kepekaan komunitas.

Proses perolehan persepsi positif komunitas tetap tidak diketahui; memperoleh informasi ini membutuhkan desain riset longitudinal dengan durasi yang tidak diketahui. Peran produk financial yang beragam (seperti: pinjaman, tabungan, kartu kredit, dll) dalam mendorong atau mendeteksi perkembangan kepekaan komunitas yang tidak diuji dalam tulisan ini. Tetapi riset ini berupaya menemukan hubungan antara bentuk lembaga \& persepsi komunitas PFSP yang disampaikan oleh responden.

Perbandingan tersebut akan menguji perbedaan karena ukuran penyedia jasa keuangan; yang terakhir hubungan antara kepekaan komunitas konsumsi dan profit dari sektor industri keuangan yang beragam (yakni; bank vs uni kredit ) yang tidak diketahui. Exemine dari pendapatan pajak Federal yang dinikmati oleh uni kredit \& anggota-anggotannya akan melengkapi apa yang masih ditanyakan dalam studi ini.

\section{SIMPULAN}

Hasil dari riset ini menjelaskan sejumlah arahan masa depan. Praktisi marketing dalam indsutri jasa keuangan akan memproleh benefit dari pemahaman yang lebih baik terhadap peran kepekaan komunitas konsumsi dalam memformulasikan strategi korporat perusahaan mereka. Misalnya; eksekutif lembaga keuangan kecil sering mengklaim bahwa ukuran mereka memberikan keuntungan kepada competitor besar dalam memperoleh penghargaan (reward) dan persepsi yang kuat dalam komunitas konsumsi antara klient-klient mereka; apakah hal ini benar? Isu-isu yang terkait termasuk perbedaan dalam hal peran ukuran bank vs unit kredit, dan perbedaan tingkat kesulitan dalam mendukung kepekaan komunitas antar customer dari 2 bentuk lembaga ini. Isu penting lainnya adalah trend dalam peersepsi konsumen komunitas konsumsi dalam industri jasa keuangan sedang tumbuh atau dalam keadaan turun?

Dan, jika turun apa yang dapat dilakukan untuk mengembalikannya? Mengapa customer pria memiliki persepsi yang lebih kuat terhadap komunitas dari pada wanita? Benefit praktis dari studi ini secara potensial memberikan keunggulan kompetitif penting bagi lembaga financial. Dan yang terakhir, langkah penting selanjutnya dalam riset kepekaan komunitas konsumsi adalah studi di luar industri 
jasa financial. Misalnya, apakah restoran membutuhkan persepsi positif keanggotaan dalam komunitas konsumsi dengan tempat makan favorit mereka?

\begin{tabular}{|c|l|l|}
\hline Nomor & Pernyataan & Pendapat \\
\hline 1$)$ & $\begin{array}{l}\text { Saya akan merekomendasikan penyedia jasa keuangan } \\
\text { (PFSP) saya kepada teman, relasi dan sejawat }\end{array}$ & 12345 \\
\hline 2$)$ & $\begin{array}{l}\text { Banyak teman, relasi \& sejawat saya juga melakukan } \\
\text { bisnis dengan PFSP saya }\end{array}$ & 12345 \\
\hline 3$)$ & $\begin{array}{l}\text { Menjadi customer PFSP saya membuat merasa sebagai } \\
\text { anggota club \& kelompok spesial }\end{array}$ & 12345 \\
\hline 4$)$ & Saya habsikan banyak waku mengunjungi teman-teman & 12345 \\
\hline 5$)$ & Kebanyakan orang dapat dipercaya & 12345 \\
\hline 6$)$ & Kebanyakan orang adalah jujur & 12345 \\
\hline 7$)$ & $\begin{array}{l}\text { Menjadi anggota sipil, sosial, atau organisasi komunitas } \\
\text { bagi saya adalah penting }\end{array}$ & 12345 \\
\hline 8$)$ & Mengerjakan pekerjaan sukarela bagi saya adalah penting & 12345 \\
\hline 9$)$ & $\begin{array}{l}\text { Saya senang menghadiri event-event yang disponsori oleh } \\
\text { PFSP }\end{array}$ & 12345 \\
\hline 10$)$ & $\begin{array}{l}\text { Mendukung secara financial lembaga non profit bagi saya } \\
\text { adalah penting }\end{array}$ & 12345 \\
\hline 11$)$ & $\begin{array}{l}\text { Saya menganggap paling tidak pegawai di PFSP saya } \\
\text { sebagai teman }\end{array}$ & \\
\hline & $\begin{array}{l}\text { Keterangan : 1 = sangat tidak setuju (strongly disagree) } \\
2=\text { sangat setuju (strongly agree) }\end{array}$ \\
\hline
\end{tabular}

Figure A2. Consumption community questionnaire

\section{DAFTAR PUSTAKA}

Ambert, A., Adler, P., Adler, P., \& Detzner, D. (1995). Understanding and Evaluating Qualitative Research. Journal of Marriage and Family, 57(4), 879-893. doi:10.2307/353409.

Albert M. Muniz, Jr., Thomas C. O'Guinn. (2001). Brand Community, Journal of Consumer Research. Volume 27, Issue 4, March, Pages 412-432, https://doi.org/10.1086/319618.

Barry, Howcroft., Hamilton Robert, Hewer Paul. (2002). Consumer attitude and the usage and adoption of home-based banking in the United Kingdom. International Journal of Bank Marketing. Volume 20, No. 3 pp.111-121. https://doi.org/10.1108/02652320210424205. 
Bloemer, J., \& Odekerken-Schöder, G. (2002). Store satisfaction and store loyalty explained by customer- and store-related factors. Journal of Consumer Satisfaction, Dissatisfaction and Complaining Behavior, 15, 60-80.

Buttle. (2005). Customer Relationship Management Concept and Tools. Elsevier.

Catano, V. M., Pretty, G. M. H., Southwell, R. R., \& Cole, G. K. (1993). Sense of Community and Union Participation. Psychological Reports, 72(1), 333334. https://doi.org/10.2466/pr0.1993.72.1.333

Chakravarty, S., et al. (2004). Relationship and individuals bank switching behavior. Journal of Economic Psychology, vol. 25, pp. 507-527.

DeYoung, R., Hunter, W.C. \& Udell, G.F. (2004). The Past, Present, and Probable Future for Community Banks. Journal of Financial Services Research. 25, 85-133. https://doi.org/10.1023/B:FINA.0000020656.65653.79

E. Fischer, B. Gainer and J. Bristor. (1996). Exploring Gendered Servicescapes. Third Gender and. Consumer Behavior Conference. Salt Lake City, Utah.

Feinberg, R., Leigh, H., Rajesh, K. and IkSuk, K. (2002), Operational determinants of caller satisfaction in the banking/financial services call center. International Journal of Bank Marketing, Vol. 20 No. 4, pp. 174-180.

Fossey, E., Harvey, C., McDermott, F., \& Davidson, L. (2002). Understanding and evaluating qualitative research. The Australian and New Zealand journal of psychiatry. 36(6), 717-732. https://doi.org/10.1046/j.14401614.2002.01100.x.

Fournier, Susan. (1998). Consumers and Their Brands: Developing Relationship Theory in Consumer Research. Journal of Consumer Research, 24 (4), $343-73$.

Goodwin, Charles. (1986). Gestures as a resource for the organization of mutual orientation. Semiotica, vol. 62 , no. 1-2, pp. 29-49

Glynn, T. J. (1981). Psychological Sense of Community: Measurement and Application. Human Relations, 34(9), 789-818. https://doi.org/10.1177/001872678103400904

Jamal, A. and Naser, K. (2002). Customer satisfaction and retail banking: an assessment of some of the key antecedents of customer satisfaction in retail. 
Jenkins, H. (2004). A Critique of Conventional CSR Theory: An SME Perspective. Journal of General Management, 29(4), 37-57. https://doi.org/10.1177/030630700402900403

Jones, T.O. and Sasser, W.E. (1995). Why Satisfied Customers Defect. Harvar d Business Review, 73.

John W. Schouten, James H. McAlexander. (1995). Subcultures of Consumption: An Ethnography of the New Bikers. Journal of Consumer Research. Volume 22, Issue 1, Pages 43-61, https://doi.org/10.1086/209434.

James H. McAlexander, Stephen K. Kim \& Scott D. Roberts. (2003). Loyalty: The Influences of Satisfaction and Brand Community Integration. Journal of Marketing Theory and Practice, 11:4, 1-11, DOI: 10.1080/10696679.2003.11658504.

James H McAlexander., John W Schouten., Harold F Koening. (2002). Building Brand Community. Journal of Marketing, Jan 2002; 66, 1; ABI/INFORM Global. pg. 38.

Kaynak and Hancar. (2005). Consumer attitudes to ards online banking: a new found three important attributes considered by consumers. Pennsylvania State University at Harrisburg .

Lasser, W.M., Manolis, C. and Winsor, R.D. (2000), "Service quality perspectives and satisfaction in private banking", Journal of Services Marketing, Vol. 14 No. 3, pp. 244-71.

Moutinho, L. and Smith, A. (2000). Modelling bank customer satisfaction through mediation of attitudes towards human and automated banking. International Journal of Bank Marketing. Vol. 18 No. 3, pp. 124-134. https://doi.org/10.1108/02652320010339699.

Nellis, Nahalel A. (2000). Deficiencies in European Monetary Union's Credible Commitment against Monetary Expansion. Cornell International Law Journal.

Oliver, Richard L. (1999). Whence Consumer Loyalty. Journal of Marketing. Volume. 63.

Oliver, R.L. (1999). Whence Consumer Loyalty. Journal of Marketing. 63, 33-34.

Pedersen, P.E., \& Nysveen, H. (2001). Shopbot banking: an exploratory study of customer loyalty effects. International Journal of Bank Marketing, 19, 146155 . 
Puddifoot, J.E. (1995), Dimensions of community identity. J. Community. Appl. Soc. Psychol., 5: 357-370. https://doi.org/10.1002/casp.2450050507

Putnam, Robert. (2000). Bowling Alone: The Collapse and Revival of American Community. New York: Simon and Schurster.

Quester, P., Lim, A. (2003). Product involvement / brand loyalty: is there a link. Journal of Product and Brand Management 12(1): 22-38.

Robert V. Kozinets. (2001). Utopian Enterprise: Articulating the Meanings of Star Trek's Culture of Consumption. Journal of Consumer Research, Volume 28, Issue 1, June 2001, Pages 67-88, https://doi.org/10.1086/321948.

Rosenberg, L.J. and Czepiel, J.A. (1984), "A MARKETING APPROACH FOR CUSTOMER RETENTION", Journal of Consumer Marketing, Vol. 1 No. 2, pp. 45-51. https://doi.org/10.1108/eb008094

Vandermerwe, Sandra. (1996). Becoming a customer "owning" corporation, Long Range Planning, Volume 29, Issue 6, Pages 770-782, https://doi.org/10.1016/S0024-6301(97)82815-4.

Williams, Ruth L., and Joseph Cothrel. (2000). Four Smart Ways To Run Online Communities. Sloan Management Review. vol. 41, No. 4. p. 81.

Yavas, U.; Benkenstein, M.; Stuhldreier, U. (2004). Relationships between service quality and behavioral outcomes: a study of private bank customers in Germany. International Journal of Bank Marketing 22(2): 144-157. doi:10.1108/02652320410521737 